\title{
ON THE AUDIT OF FAIR VALUE MEASUREMENTS
}

\author{
Jatinder P. Singh* and Prince Doliya \\ Department of Management Studies, Indian Institute of Technology Roorkee, Uttarakhand, India
}

In this article, the hypotheses „whether the auditor's functional domain, his approach, methodology and responsibilities are undergoing a metamorphosis with the adoption of Fair Value Accounting (hereinafter the "FVA") and whether his/her role is moving away from the mechanized attester of tangible evidence to the one exercising a substantively judgmental function in a holistic assessment of the values ascribed to be fair by the entity's management" are tested. These hypotheses are tested on the basis of an analysis of the statutory provisions, the pronouncements of accounting and other regulatory bodies and accounting norms and theories. After setting forth the research objectives and the hypotheses, the necessity of the FVA is reviewed and the underlying philosophy is analyzed. Impediments in performing audits of fair-valuebased measurements are then identified and the US auditing standards and their international counterparts are touched upon. Finally, some safeguards and precautions for the auditor in an audit of fair-value measurements are presented.

Keywords: Fair Value Accounting (FVA), procedures for Fair Value Measurements (FVMs), fair value estimates, impediments to an audit of FVMs, the audit standards and pronouncements on fair value auditing

JEL Classification: M41, M42

\section{INTRODUCTION}

The importance of the "audit" function in the corporate regulatory framework has monotonically been increasing in the last decade along with the gradual adoption of the Fair Value Accounting (FVA) by accounting regulators across the world. In this revolutionized environment, the auditor's functional domain, his approach, methodology and the nature of his responsibilities have all been undergoing a metamorphosis. The auditor's role is moving away

\footnotetext{
*Correspondence to: J .P. Singh, Department of Management Studies ,Indian Institute of Technology Roorkee, 247667 Uttarakhand, India; e-mail: jpsiitr@gmail.com
}

from a conventional, mechanized attester of tangible evidence to the one that exercises an exceedingly judgmental function in a holistic assessment of (sometimes highly subjective) substantiation of the values ascribed to be fair by the entity's management. Resourceful audit firms do have organized training and development mechanisms set in place for their staff to ensure that such staff remain adequately educated and technically equipped in the contemporary aspects of the profession. Nevertheless, the incessant development of complex and innovative financial instruments and novel business practices demanding an application of innovative valuation models and assumptions present an unrelenting challenge (Martin, Rich \& Wilks, 2006, 287; Smith-Lacroix, Durocher \& Gendron, 2012, 36). 
The Public Company Accounting Oversight Board (hereinafter the "PCAOB”) of the United States has gone on record stating that auditors are inadequately prepared to confront complicated issues in relation to evaluating Fair Value Measurements (FVMs) (Bratten, Gaynor, McDaniel, Montague \& Sierra, 2013, 7; Cannon \& Bedard, 2014, 1). Several other studies also highlight the fact that neither corporate accountants nor auditors have been able to keep pace with the progression and developments in this area resulting in a massive competency gap that poses serious challenges to the professional accounting bodies and regulators. In their analysis of the Enron scandal, G. J. Benston and A. L. Hartgraves (Benston \& Hartgraves, 2002, 105) inferred that the auditing staff of Enron's statutory auditors (Arthur Andersen LLP) were unable to understand the implications of the complex financial status and mechanisms established by Enron's CFO, "Andrew Fastow." It seemed to the said authors that Andersen's technical staff were relatively more conversant with the profile of Enron's oil and gas business, but failed to completely apprehend the implications of the company's newly-instituted activities in innovative financial instruments. This, probably, led to the inadequate and non-contextual reporting by the company's auditors in their Annual Reports. The Enron case provides an immediate illustration of one of the cardinal impediments to the universal adoption of the FVA viz. the difficulties associated with the attestation thereof.

In the defense of Andersen, one could claim that an audit firm cannot possibly be expected to possess "expert" resources in every business activity of the modern complex commercial world. However, accounting regulators invariably provide for the engagement of "specialists" by audit firms and permit such audit firms to use and integrate specialists' reports in their own audit report. In the United States, while accepting that auditors cannot be proficient in all intricate or subjective matters of an audit, AU Sec. 336 (AU Sec 336, Work of a Specialist, AICPA, 1998) does mandate that they must have sufficient understanding in order to evaluate the adequacy of specialists' work, in case such specialists are engaged by an audit firm.

Generally, auditors need to take a call on when to have a specialist engaged and how to incorporate and interpret a specialist's work into the main audit process. It is true that using specialists in an audit team adds an additional layer of complexity to the audit influencing the audit team's structure, incentives, and culture sharing within firms. However, audit firms need to have a broader perspective of the issues involved. Indeed, in the last decade, there has been an increasing trend of engaging specialists' expertise in fair value auditing. Hopefully, this trend will increase with the proposed harmonization of accounts and the implementation of the International Financial Reporting Standards (IFRS) throughout the world (Joe, Vandervelde \& $\mathrm{Wu}, 2014,1)$.

The aforesaid backdrop sets up the context of this research. The subject of this study is identified as a threadbare analysis of the concept of "fair value accounting" from the perspective of the "statutory auditor". Specifically, (a) whether the role of the auditor has undergone a significant transformation consequent to the progressive adoption of fair-valuebased measurements in statutory accounting and (b) identifying the impediments encountered by the auditor in performing audits of fair value based measurements will be examined. Along the way, the extent of harmonization between the US auditing standards and their international counterparts in the context of an audit of FVMs, together with the implications thereof, will also be elucidated.

Thus, the main goal of this paper is to perform a holistic examination of the impact of the induction of the FVA on an auditor's profile, including his functional domain, approach, methodology and responsibilities. It also attempts to review the changes in the audit process necessitated for performing an audit of fair value measurements.

In view of the research objectives set out above, the following null hypotheses $\mathrm{H}_{0}^{(i)}$ are set up for testing:

$\mathrm{H}_{0}^{(1)}$ : An auditor's profile i.e. his functional domain, approach, methodology and responsibilities do not undergo any change due to the induction of fair value accounting into the statute books.

$\mathrm{H}_{0}^{(2)}$ : No changes are necessitated in the audit process for performing an audit of fair value measurements. 
with the usual alternative hypotheses $\mathrm{H}_{1}^{(1)}$ and $\mathrm{H}_{1}^{(2)}$.

These hypotheses are tested on the basis of an analysis of various statutory provisions, the pronouncements of professional accounting and other regulatory bodies and accounting norms and theories.

Having presented the research subject and objectives, and having set up the research hypotheses to be tested, we proceed to review the issue of the necessity of the FVA in Section 2 and provide a critical conceptual assessment of the FVA in Section 3. These two sections facilitate an appreciation of the rationale behind the progressive adoption of the FVA by the accounting fraternity worldwide. They also enable a clear understanding of the philosophical, theoretical and practical underpinnings of the FVA, necessary to comprehend the nuances of an audit of FVMs. Section 4 constitutes the mainstay of this paper, presenting therein the impediments faced by an auditor in an audit of FVMs. The cardinal pronouncements on an audit of FVMs by statutory accounting/ auditing bodies are elaborated in Section 5. Herein, the issues of international harmonization in the context of this work are also discussed. Safeguards and precautions for auditors in an audit of FVMs, identified in the course of this study, are set forth in Section 6. Section 7 concludes with a summary of the findings, the limitations of this work and the directions for future work in this field. It is emphasized that, in lieu of an initial section on an integrated review of the literature, the sequential literature review in each section to the extent required is presented.

\section{WHY HAVE FAIR VALUE ACCOUNTING?}

In an idealized setting, the financial statements of an entity should represent the „economic reality”. In this vein, a "profit" should manifest itself as an accretion in the overall market value of the entity. Equivalently stated, a ,profit" should be computed as the incremental worth of the enterprise assessed at the marketplace for the accounting period. Allow us to present an example to illustrate this point. Take a manufacturing company purchasing raw materials and other resources from the market, converting them to finished products and selling these products to generate its revenue stream.
It is seen that a depletion of assets occurs on the one hand, for example, a decrease in the economic life (and therefore the economic worth) of the various fixed assets involved in the production process and the consumption of stores and a raw material. On the other hand, there occurs a creation of assets because of the realization of sale proceeds. If the latter exceeds the former, the excess is termed as a "profit". To reiterate, then, a "profit" earned by an entity in an accounting period is an accretion in market value of the entity during that period. This is also justified on the count that a profit earned during the period must be reflected in an increase in the aggregate assets of the enterprise.

This nexus between a profit and a value leads us to the philosophy of the FVA. Conventionally, the historical cost has substantively been the underlying valuation methodology of all accounting statements. However, the fallibilities of Historical Cost Accounting (hereinafter the "HCA") are well documented. To take the case of "fixed assets", the amortization of such assets over their economic life is, for the most part, arbitrary because the consumption pattern of such assets is not amenable to a precise mathematical model. The other option of ascertaining their economic value empirically at the end of each accounting period is equally impracticable on the counts of substantial expenditure for the exercise as well as the limited accuracy and reliability of the results. It is, therefore, usual to impute a consumption pattern to such assets and amortize them on that basis. The saving grace here is that improper amortizations merely result in timing differences in the recognition of profits across different accounting periods. However, an aggregate profit earned over the life of an entity remains unchanged. Even in the case of current assets, in times of consistently falling prices, non-existent reserves would accumulate in the accounts of an entity if historical cost valuations were adopted for such assets due to an overvaluation of stocks.

It is, thus, obvious that even in the simplest business scenario, the HCA is plagued with many inconsistencies. It is no surprise, therefore, that there is a marked unrest in the accounting fraternity against the HCA. A vigorous campaign is in process in the United States to marshal in the FVA reforms. In essence, the incongruity between the HCA and the 
FVA is essentially a manifestation of the long-standing „reliability” versus „relevance” debate. Until recently, the accounting fraternity across the world was obsessed with a clear conviction of the preeminence of „reliability” over „relevance”. Accounting regulators and auditing professionals were the emphatic votaries of the former, for the obvious reason that conventional "vouching" formed the mainstay of the auditing process and transactions were, largely, objectively verifiable as a consequence (Singh \& Uzma, 2011, 113).

Accounting regulators invariably prescribe "true and fair" as the overriding qualification for all financial statements. The UK Companies Act 2006 contains this provision in Sec 393. Therefore, financial statements need necessarily present a "true and fair" picture of financial affairs of the reporting entity. Partly as a consequence of the gradual social and scientific evolution processes and partly due to the increasing complexities of the implications of contemporary financial products and transactions, it is, now, widely perceived that HCA-based statements fail to fairly report the information of the reporting entity in the manner and to the extent that they are required to. It is, therefore, being increasingly felt necessary that recourse be had to the FVA as the primary reporting methodology (on the premise that FVMs are substantially more "relevant") and the use of the HCA be confined to the accounting of fixed assets wherein any differences in valuations would merely result in "timing differences" in the recognition of income. In particular, the two areas where the FVA is very conspicuous by its presence are:

- the accounting and valuation of intangible assets;

- the accounting and valuation of financial instruments.

In the former case, the "cost of acquisition" is usually not representative of the "future economic benefits" from the asset, while in the latter, the price processes of the underlying assets/liabilities as well as derivative instruments are stochastic, i.e. they are the functions of random variables. Hence, the historical cost of these instruments gradually loses its descriptive nature of the functional value of the instrument.

In the context of the fair-value-based reporting of derivatives, it is pertinent to mention here that, in the normal course, i.e. when such derivatives are held on their own as open positions, their reporting must necessarily be marked to the market. Nevertheless, in situations where an entity can establish that such instruments are being held for the hedging of other open positions, the benefit of "hedge accounting" is allowed to the reporting entity. Hedge accounting enables an entity to enjoy the privilege of offsetting gains and losses on the derivative positions in the same period as the income of the hedged asset or a liability. The underlying philosophy of hedge accounting is that, if offsetting is not allowed, the timing mismatch of the recognition of income effects on the two opposite but correlated positions results in an investor's unnecessary perception of an income volatility (Landsman, 2007, 19; Veron, 2008, 63; Magnan, 2009, 189; Alexander, Bonaci \& Mustata, 2012, 84).

\section{WHAT IS FAIR VALUE ACCOUNTING?}

The FVA is defined as the accounting system in which assets and liabilities are reported at their respective estimated current values. The FVA is therefore also known by the name of "mark to market accounting" (FAS 157, FASB, USA). A "fair value" is defined in FAS 157 as ,the price that would be received to sell an asset or paid to transfer a liability in an orderly transaction between market participants at the measurement date".

"Measurement" constitutes the cardinal activity in the process of financial reporting (Barth, 2006, 271). The activity of "measurement" consists of two parts viz. (a) identifying a valuation base with respect to which measurement is to be made and (b) computing the value of the asset/liability in the selected valuation base. Fair value measurement requires using one of the three valuation bases viz. (a) the income approach, which capitalizes the projected income stream from the asset; (b) the cost approach that defines the cost as the current replacement value; or (c) the market value approach that adopts prices and other related factors used in market deals in the same or commensurable assets or liabilities. This valuation base adopts market multiples derived from a set of comparisons. 
The methodology for the ascertainment of a fair value is elaborately prescribed in FAS 157. However, the various situations wherein the FVA-based measurements are to be used for reporting are not explicitly stated in FAS 157. Nevertheless, there are several other standards that do unambiguously mandate the use of FVMs for reporting purposes e.g. for financial derivatives (FAS 133, FASB, USA), intangible assets (FAS 141,142, FASB, USA) etc.

To ensure a consistency in FVMs, FAS 157 provides for a three-level hierarchy of valuation inputs for the purpose of estimating the fair value of an asset or a liability. These levels explicitly enumerate relevant valuation inputs under different marketability scenarios of the asset or a liability. In essence, they represent the best available sources of data for the valuation in the said marketability scenario (FAS 157, FASB, USA).

\section{IMPEDIMENTS IN AUDITING OF FAIR VALUE MEASUREMENTS}

At the very outset, it needs to be emphasized that FVMs are essentially market-based, either directly or indirectly, and such market-based valuations may not necessarily reflect the quantum of the "future economic benefits" that may be derived from an asset, i.e. its intrinsic value (Pannese \& DelFavero, 2010). In particular, the "intrinsic value" of an asset is always valuer-dependent. To this extent, the very genesis of the FVA is flawed. However, we shall confine ourselves herein to the issues of the auditing of the measurements of fair values as prescribed in the 3-level input hierarchy referred to in the preceding section viz.

Level 1: These are market inputs reflecting quoted prices for identical assets or liabilities in active markets;

Level 2: These are: (a) market inputs reflecting quoted prices for identical assets or liabilities in inactive markets, or quoted prices for similar assets or liabilities in all markets, adjusted for differences; (b) market inputs other than quoted prices, such as interest rates, yield curves, volatilities, and default rates; (c) market inputs not directly observable for an asset or a liability, but corroborated by other market data through correlation or other means;

Level 3: These inputs are entity inputs.

It is obvious that FVMs based on Level 1 inputs should present a small difficulty to the auditor on account of the existence of substantively objective evidence and consequently, limited discretion for an entity's management in ascribing the fair value. The problem level for the auditor, however, escalates as we move down the input level hierarchy with the dilution of the objectivity of the substantiating evidence supporting the management's estimates of a fair value. Verifiability and, consequently, reliability become the cardinal issue for Level 2- or Level 3-based valuations because such valuations are essentially obtained as theoretical market prices. In fact, Level 3 inputs are, for all intents, unobservable and internal to an entity. Consequently, the resulting valuations are the prices representing the management's opinion of the market dynamics in relation to the asset being valued. It immediately follows that Level 3-based valuations are susceptible to a measurement error at least on two counts viz. (a) (an) error(s) in the modelling of the relevant price processes and (b) (an) error(s) in the assumptions and other inputs that go into the model for the estimation of the market price in the stipulated (hypothetical) market set up. Both these types of errors could emanate from the existence of intentional or unintentional biases and prejudices of the management. To that extent, FVMs become immensely more vulnerable to manipulations by deceitful stakeholders with audits, even by professionals of uncompromising integrity, being rendered substantively ineffective (Benston, 2008, 101; Griffith, Hammersley \& Kadous, 2014; Griffith, Hammersley, Kadous \& Young, 2014). In fact, several empirical studies point to the presence of a conscious bias on the part of an entity's management in FVMs (Dietrich, Harris \& Muller, 2001, 125; Hodder, Mayew, McAnally \& Weaver, 2006, 933; Danbolt \& Rees, 2008, 271; Ramanna, 2008, 253; Ramanna \& Watts, 2009). 


\section{PRONOUNCEMENTS ON AUDITING OF FAIR VALUE MEASUREMENTS}

In view of the issues highlighted in the preceding section, several accounting regulators and professional accounting bodies have come up with guidelines/ norms in relation to auditing of FVMs in attempts to rationalize the relevant audit procedures and provide them with a statutory backup. These assertions, obviously, enhance the reliability of FVMs (Bell \& Griffin, 2012, 147). The cardinal pronouncement in this regard in the United States is SAS No. 101 (AU Sec. 328, AICPA 2003). It provides for a general audit approach for FVMs and related disclosures. Although this standard does not provide specific guidance for auditing specific assets, liabilities, or equity items reported at fair value, it does contain a methodology for the audit of FVMs in general. This standard unambiguously lays the onus for the making of FVMs on a company's management. It requires an entity's management to:

- establish accounting and reporting processes for determining FVMs,

- identify proper estimation procedures,

- report and justify any noteworthy assumptions used,

- formalize valuations, and

- ensure that FVMs reported together with disclosures thereon are in conformity with the GAAP (AU Sec. 328.04, AICPA 2003).

The said standard also casts responsibility on auditors (a) in Sec AU 328.09, to obtain ample knowledge of the processes and relevant controls in an entity for determining FVMs and (b) in Sec AU 328.18 \& 328.28 , to assess whether an entity's approaches to the computation of FVMs and significant assumptions are appropriate and likely to offer a rational foundation for FVMs and associated reporting in an entity's accounts. It follows that the auditor must have knowledge and understanding of how a particular FVM should be (and has been) derived in order to determine whether the client's approach is appropriate (Abernathy, Hackenbrack, Joe, Pevzner \& Wu, 2014).
Instances of audit pronouncements in the United States that apply to specific assets include (a) Auditing Derivative Instruments, Hedging Activities, and Investments in Securities, (SAS No. 92, AU Sec 332, AICPA 2000), (b) Auditing Fair Value Measurements and Disclosures: A Toolkit for Auditors (AICPA 2003). The latter guidelines relate to the FVMs required by FAS No. 141 (FAS 141, FASB, USA), Business Combinations, FAS No. 142 (FAS 142, FASB, USA), Goodwill and Other Intangible Assets, and FAS No. 144 (FAS 144, FASB, USA), Accounting for the Impairment or Disposal of Long-Lived Assets.

The International Standard on Auditing (ISA) 540, Auditing Accounting Estimates, Including Fair Value Accounting Estimates, and Related Disclosures (ISA 540 , IASB) seems to be the counterpart of SAS No 101 in the IFRS framework. This standard sets forth the overall methodology for audit of fair values and other estimates. This auditing standard is premised on the audit risk model. It stipulates that the auditor must lay emphasis during the course of his audit on aspects involving a high probability of error or involving a substantive subjective judgment or carry a possibility of biases and prejudices on the part of the estimator. In analogy with SAS 101, the ISA 540 also requires auditors to obtain an understanding of the underlying methodology adopted by the entity's management for computing FVMs. He must also scrupulously scrutinize data on which such FVMs are based. This knowledge would enable the auditor to assess the chances of significant errors having crept into FVMs. To facilitate this, auditors must (a) examine internal control mechanisms in vogue in an enterprise in relation to FVMs, (b) evaluate the underlying valuation models used for FVMs and test them for appropriateness, and (c) check the assumptions that form the premise of the valuation model for an adequate representation of reality as well as for an inter se consistency. Furthermore, in formulating his opinion on a particular risk scenario or stimulus, the auditor may also take account of events after the balance sheet date. It would be more proprietary for the auditor to develop independent estimates of relevant FVMs and then compare his own estimates with the corresponding values obtained by the entity's management (Kumarasiri \& Fisher, 2011, 661; Christensen, Glover \& Wood, 2013, 36). 


\section{SAFEGUARDS AND PRECAUTIONS IN AUDITING FVMS}

The essentials of a professional FVM audit program are engrained in the auditing standards, a few of which have been referred to in the preceding paragraphs. The perusal of these standards leads to the following cardinal aspects of an FVM audit viz. (a) examining internal controls in relation to FVMs, (b) identifying those FVMs that are susceptible to a high probability of an error or a bias, and directing audit resources to a comprehensive examination of all aspects of such FVMs, (c) consciously making efforts to minimize any chance of an auditor's biases creeping into an audit (Martin et al, 2006, 287). We discuss these issues in greater detail in the sequel.

\section{Assessing Internal Controls in Relation to FVMs}

Assessing internal controls in vogue in the client's workplace constitutes the backbone of the entire audit process. The premises on which these controls are formulated, the extent to which they have been backtested and, thereafter, implemented in the organization would have to be examined. In the context of internal controls in relation to FVMs, one must necessarily emphasize that when assets are measured at fair value, such measurements rely on assumptions and projections of the future and, as mentioned earlier, such measurements involve a two-step process (explicitly or implicitly) viz. (a) modelling the market dynamics and (b) providing necessary inputs to the model. Evaluating and, indeed, establishing controls for either of these is a difficult exercise. Not only this, each FVM is likely to have its singularities necessitating the setting up of controls on an application-by-application basis (usually, uniform control systems exist for traditional transaction processes). Thus, an audit of FVM internal control systems requires substantially more enterprise and commitment on the part of the auditor. Added to this is the fact that the FVA is presently in a state of flux with rapid evolutionary changes and upgradations. The control systems of the client as well as those of the auditor must keep pace with this dynamism.

\section{Identifying and Evaluating FVMs that are Likely to be a Higher Risk}

AU Sec 328.33 (AU Sec. 328.33, AICPA 2003) describes assumptions significant to FVMs as those that (a) materially affect FVMs and (b) may be characterized by sensitivity to variation, uncertainty in the amount or nature, or susceptibility to a misapplication or a bias.

Auditors must identify such material assumptions and obtain from the management representations about such assumptions used in determining FVMs (AU Sec. 333, AICPA 1997, App. B). Additionally, auditors are also required to exercise a judgment when evaluating (a) significant underlying assumptions of the management in formulating FVM models, (b) the FVM valuation models themselves, as well as (iii) the sources and consistency of data that are an input into the FVM model (AU Sec. 328.26, AICPA, 2003).

It is believed that, rather than evaluating the judiciousness of the estimates of FVMs obtained by an entity's management and the basis thereof, auditors would be better off producing their own independent estimates and thereafter comparing them with the management's estimates. If the estimates so obtained from the two sources lie within acceptable ranges, the auditor's confidence in the management's assessment is buoyed. On the contrary, if there are significant variations existing between the two sets of estimates, auditors must necessarily probe further and, possibly, have recourse to the expertise of specialists so as to satisfactorily analyze variations and arrive at a consistent set of estimates (Brehmer, 1980, 223). In the long run, audit firms may acquire sufficient proficiency to produce quality independent estimates as they acquire data on how similar FVMs are made across various clients. Nevertheless, until such adeptness is developed, auditors may have to rely on their theoretical knowhow and unhesitatingly take assistance of valuation specialists to gain assurance.

\section{Potential Biases of an Auditor}

This aspect of auditing in an FVA environment is referred to in SAS No 92, AU Sec 332.35 which reads as follows: "The auditor should obtain evidence 
supporting management's assertions about the fair value of derivatives and securities measured or disclosed at fair value. (AU Sec. 332.35, AICPA 2000)".

A literal construction of this instruction would require auditors to merely search for and obtain evidence to support the assertions of the management but none that might disconfirm the assertions. This would result in a definite and strong possibility of a confirmation bias in auditors' reasoning. The existence of such a bias is well researched and documented. The research recommends that, in the context of auditing FVMs, auditors must necessarily ensure that they identify, consider and assess not only confirming evidence but also disconfirming evidence for the assumptions and other inputs that go into the FVM process. The existence of evidence asserting an assumption or an input of the FVM process different from that the one adopted by the management should also be explored and, if it exists, given its due consideration and weightage (Koonce, 1992, 59).

There is another important source of bias that the auditor needs to guard against. Empirical work (Paese \& Sniezek 1991, 100; Davies, Lyhse \& Kotterman, 1994, 253) indicates that auditors tend to become more assured of their estimates with an increase in the size of the information set without really appreciating the quality of each incremental piece of information. Auditors need to take this as a serious caveat since, for most FVMs, data are extensively available. Further, most such data could usually be ambiguously interpreted i.e. such data may be qualitatively quite poor in relation to the target application. Sometimes, it may also be the case that auditors tend to over-rely on their own perceived expertise, thus showing reluctance to engage specialists. This aspect also needs to be suppressed in order to enhance audit effectiveness.

\section{CONCLUSION}

The aforesaid analysis of the statutory provisions, regulatory and professional pronouncements in relation to the FVA unambiguously rejects both the "null" hypotheses, set up in Section 1 of this paper, and leads to the acceptance of the "alternative" hypotheses viz.
$\mathrm{H}_{1}^{(1)}$ : The auditor's profile, i.e. his functional domain, approach, methodology and responsibilities, has undergone a metamorphosis due to the induction of fair value accounting into the statute books.

$\mathrm{H}_{1}^{(2)}$ : Significant changes are necessitated in the audit process for performing an audit of fair value measurements.

The Financial Accounting Standards Board of the United States has pioneered the introduction of the FVA into the accounting manual with the pronouncement of FAS 157 read with FAS 133, 141 and 142. Adversaries of the FVA would have a lot to say about the pitfalls of the FVA on the lines of this article. It is fair to say that the current study has highlighted the cardinal shortcoming of the FVA. There is a universal consensus that accounting information needs to be adequately auditable. Non-adherence to this maxim would lead to an erosion of the reliability of such information to the extent that it would become unacceptable to the users thereof. In this context, numerous impediments to a precise audit of FVMs have been elucidated in the above paragraphs. It is, thus, evident that the FVA, as it stands of now, is certainly not a panacea for all accounting evils. Substantially more reformation of the FVA, particularly as to the practical issues embedded therein, needs to be done. Several pronouncements by accounting regulators in relation to the audit of FVMs have paved the way forward in this direction. Some safeguards and precautions have also been suggested herein. The instances of the harmonization between the US auditing standards and their international counterparts in the context of the audit of FVMs together with the implications thereof are also explained. One, however, must necessarily appreciate that, in most cases, FVMs are intrinsically imprecise and, consequently, the audit thereof can rarely be perfect. Nevertheless, the threshold level of the accuracy of FVMs and the effectiveness of their audit must be sustainable so that users of accounting statements could adopt them without casting aspersions on their reliability.

It must, however, be emphatically underscored that this is purely a theoretical study. Although the findings seem to be unequivocal, the authors' perceptions, biases and interpretations would nevertheless find a way to 
influence the inferences. Hence, it is always desirable to substantiate these findings with empirical evidence for corroboration. In fact, this could be a possible avenue for further research. However, the inferences drawn from the application of statistical methods also need to be accepted with a caution, howsoever sophisticated these tools may be. Ideally, a conceptual analysis of a problem should be indisputably validated by empirical findings for a reliable inference.

Furthermore, this study explores the aspects of human decision-making, and studies such as this suffer from intrinsic limitations. Since there is no extant mathematical apparatus that can model the cerebral activity with precision, we, as of today, do not have a mechanism whereby we can frame a set of evolution equations that could possibly lead to an exact solution to such problems. Additionally, the problem with this type of subjective hypotheses is "how do we interpret what is significant and what is not?" In other words, we must ascribe a certain quantitative definition to "significance" or ascribe a threshold figure to accept that a particular test statistic value below/above that figure implies significance; otherwise, the testability of the hypothesis is diluted. While this is a general observation, in the context of the current study, the analysis undeniably supports the "alternative hypotheses" and so no ambiguity is inferred. Hence, the subjective hypotheses set up in Section 1 seem to work adequately. This may not always be the case, though.

Nevertheless, there is no disputing the "relevance" of the FVA in a contemporary business scenario. In fact, this observation sets in place the research agenda in this field. At the near end of the spectrum, one could perform an empirical study using a diverse sample from the auditing fraternity to validate the findings of this conceptual study. The FVA is widely being viewed as the precursor of a comprehensive overhaul of the accounting profession. Like any new concept, the FVA is facing the so-called "teething troubles". However, it needs to be nurtured through this infancy to enable it to strengthen its roots in accounting theory. At the distant end of the spectrum, therefore, research programs could be initiated by accounting regulators and practitioners' forums to identify and implement measures for enhancing the reliability of FVMs (Cohen
\& Knechel, 2013, 1). In this context, it is pertinent to note that, as of now, the FVA manifests itself conspicuously in only a few sectors, e.g. financial assets and liabilities, intangibles, mergers and acquisitions and pension accounting. If the enhanced reliability of FVMs can be achieved, its role in financial reporting may also escalate in due course. Therefore, one could look at the medium-term research avenues that (a) explore the shortcomings/limitations of the FVA in its current applications or (b) identify further sectors/areas where the FVA could be introduced in order to improve the quality of financial reporting.

\section{REFERENCES}

Abernathy, J. L., Hackenbrack, K., Joe, J. R., Pevzner, M., \& Wu, Y. J. (2014). Comments of the Standards Committee of the Auditing Section of the American Accounting Association on PCAOB Staff Consultation Paper Auditing Accounting Estimates and Fair Value Measurements. Current Issues in Auditing, 8(2), C1-C7. doi: http://dx.doi.org/10.2308/ciia-51013

Alexander, D., Bonaci, C. G., \& Mustata, R.V. (2012). Fair value measurement in financial reporting. Procedia Economics $\mathcal{E}$ Finance, 3, 84-90. doi: 10.1016/S2212-5671(12)00124-4

Barth, M. (2006). Including estimates of the future in today's financial statements. Accounting Horizons, 20(3), 271-285. doi: http://dx.doi.org/10.2308/acch.2006.20.3.271

Bell, T. B., \& Griffin, J. B. (2012). Commentary on auditing high-uncertainty fair value estimates. Auditing: A Journal of Practice \& Theory, 31(1), 147-155. doi: http://dx.doi.org/10.2308/ ajpt-10172

Benston, G. J. (2008). The shortcomings of fair-value accounting described in SFAS 157. Journal of Accounting and Public Policy, 27(2), 101-114. doi: 10.1016/j.jaccpubpol.2008.01.001

Benston, G. J., \& Hartgraves, A. L. (2002). Enron: What happened and what we can learn from it? Journal of Accounting and Public Policy, 21(2), 105-127. doi:10.1016/S02784254(02)00042-X

Bratten, B., Gaynor, L. M., McDaniel, L., Montague, N. R., \& Sierra, G. E. (2013). The audit of fair values and other estimates: The effects of underlying environmental, task, and auditor-specific factors. Auditing: A Journal of Practice E Theory, 32(1), 7-44. doi: http://dx.doi.org/10.2308/ajpt-50316

Brehmer, B. (1980). In one word: Not from experience. Acta Psychologica, 45(1-3), 223-241. doi:10.1016/0001- 
6918(80)90034- 7

Cannon, N. H., \& Bedard, J. C. (2014). Auditing challenging fair value measurements: Evidencefrom the field. Available at SSRN, 1. http://dx.doi.org/10.2139/ssrn.2220445

Christensen, B E., Glover, S. M., \& Wood, D. A. (2013). Extreme estimation uncertainty and audit assurance. Current Issues in Auditing, 7(1), P36-P42. doi: http://dx.doi.org/10.2308/ciia50447

Cohen, J. R., \& Knechel, W. R. (2013). A Call for academic inquiry: Challenges and opportunities from the PCAOB synthesis projects. Auditing: A Journal of Practice \& Theory, 32(1), 1-5. doi: http://dx.doi.org/10.2308/ajpt-10331

Danbolt, J., \& Rees, W. (2008). An experiment in fair value accounting: UK investment vehicles. European Accounting Review, 17(2), 271-303. doi: 10.1080/09638180701819865

Davies, F. D., Lyhse, G. L., \& Kotterman, J. E. (1994). Harmful effects of seemingly helpful information on forecasts of stock earnings. Journal of Economic Psychology, 15(2), 253-267. doi:10.1016/0167-4870(94)90003-5

Dietrich, J. R., Harris, M., \& Muller, K. (2001). The reliability of investment property fair value estimates. Journal of Accounting and Economics, 30(2), 125-158. doi:10.1016/S01654101(01)00002-7

Griffith, E. E., Hammersley, J. S., \& Kadous, K. (2014). Audits of complex estimates as verification of management numbers: How institutional pressures shape practice. Contemporary Accounting Research, 31(4), doi: 10.1111/1911-3846.12104

Griffith, E. E., Hammersley, J. S., Kadous, K., \& Young, D. (2014). Auditor mindsets and audits of complex estimates. Journal of Accounting Research, 52(5), doi: 10.1111/1475-679X.12066

Hodder, L. D., Mayew, W., McAnally, M. L., \& Weaver, C. D. (2006). Employee stock option fair value estimates: Do managerial discretion and incentives explain accuracy? Contemporary Accounting Research, 23(4), 933-975. doi: 10.1506/ ML46-8401-6222-4642

Joe, J. R., Vandervelde, S. D., \& Wu, Y. (2014). Use of third party specialists' reports when auditing fair value measurement: Do auditors stay in their comfort zone. 2014 Deloitte Foundation/University of Kansas Auditing Symposium.

Koonce, L. (1992). Explanation and counter-explanation during audit analytical review. The Accounting Review, 67(1), 59-76. available at http://www.jstor.org/stable/248020

Kumarasiri, J., \& Fisher, R. (2011). Auditors' perceptions of fair-value accounting: Developing country evidence. International Journal of Auditing, 15(1), 66-87. doi: 10.1111/j.10991123.2010.00423.x

Landsman, W. R. (2007). Is fair value accounting information relevant and reliable? Evidence from capital markets. Accounting \& Business Research, 37(12), 19-30. doi: 10.1080/00014788.2007.9730081.

Magnan, M. (2009). Fair value accounting and the financial crisis: Messenger or contributor. Accounting Perspectives, 8(3), 189-213. doi: 10.1506/ap.8.3.1

Martin, R., Rich, J., \& Wilks, J. (2006). Auditing fair value measurements: a synthesis of relevant research. Accounting Horizons, 20(3), 287-303. doi: http://dx.doi.org/10.2308/ acch.2006.20.3.287

Paese, P. W., \& Sniezek, J. A. (1991). Influences on the appropriateness of confidence in judgments: Practice, effort, information, and decision-making. Organizational Behavior and Human Decision Processes, 48(1), 100-130. doi:10.1016/07495978(91)90008-H

Pannese, D. A., \& Delfavero, A. (2010). Fair value accounting: Affect On the auditing profession. Journal of Applied Business Research, 26(3), 43-50.

Ramanna, K. (2008). The implications of unverifiable fair value accounting: Evidence from the political economy of goodwill accounting. Journal of Accounting \& Economics, 45(2-3), 253-281. doi:10.1016/j.jacceco.2007.11.006

Ramanna, K., \& Watts, R. (2009). Evidence from goodwill nonimpairments on the effects of using unverifiable estimates in financial reporting. Working paper no. 09-106, Harvard Business School.

Singh, J. P., \& Uzma, S. H. (2011). Fair value accounting: Virtues and vices. International Journal of Managerial \& Financial Accounting, 3(2),113-126. DOI 10.1504/IJMFA.2011.039492

Smith-Lacroix, J. H., Durocher, S., \& Gendron, Y. (2012). The erosion of jurisdiction: Auditing in a market value accounting regime. Critical Perspectives on Accounting, 23(1), 36-53. doi:10.1016/j.cpa.2011.09.002

Veron, N. (2008). Fair value accounting is the wrong scapegoat for the crisis. European Accounting Review, 5(2), 63-59. DOI:10.1080/17449480802510542 
Jatinder Pal Singh, PhD, is a Professor at the Indian Institute of Technology, Roorkee, India, and a professional member of the Institute of Chartered Accountants of India, the Institute of Cost Accountants of India, the Institute of Company Secretaries of India and the Institution of Engineers (India). His research interests are in financial accounting and auditing, financial risk management, econophysics and international finance.

Prince Doliya is a research scholar in business administration, at the Indian Institute of Technology Roorkee, India. His research interests are in financial accounting and auditing, management accounting and corporate governance.

\title{
O REVIZIJI MERENJA PRAVIČNE VREDNOSTI
}

\author{
Jatinder P. Singh i Prince Doliya \\ Department of Management Studies, Indian Institute of Technology Roorkee, Uttarakhand, India
}

U ovom radu, testirane su dve hipoteze: „da li se funkcionalni domen revizora, njegov pristup, metodologija i odgovornosti preobražavaju usvajanjem računovodstva zasnovanog na pravičnoj vrednosti (RPV) i da li se uloga revizora pomera sa njegove uloge mehaničkog overavača materijalnog dokaza na ulogu vršioca kritičke funkcije u holističkoj proceni vrednosti kojima uprava datog subjekta pripisuje kvalitet pravičnosti“. Navedene hipoteze testirane su na osnovu analize zakonskih odredaba, zvaničnih računovodstvenih mišljenja i drugih regulatornih tela i računovodstvenih normi i teorija. Nakon postavljanja istraživačkih ciljeva i hipoteza, analizirane su neophodnost RPV-a i filozofija na kojoj ono počiva. Zatim, identifikovane su smetnje u reviziji merenja pravične vrednosti, i razmotreni revizorski standardi u Sjedinjenim Američkim Državama i drugim zemljama. Takođe, predstavljene su neke mere zaštite i opreza, na koje revizor treba da obrati pažnju prilikom revizije merenja pravične vrednosti.

Ključne reči: računovodstvo zasnovano na pravičnoj vrednosti, procedure za merenje pravične vrednosti (MPV), procene pravične vrednosti, smetnje u reviziji MPV, standardi revizije i zvanična mišljenja o reviziji zasnovanoj na pravičnoj vrednosti 